Article

\title{
The Effect of Membrane Material and Surface Pore Size on the Fouling Properties of Submerged Membranes
}

\author{
Sungil Jeon ${ }^{1}$, Saeid Rajabzadeh ${ }^{1,2}$, Ryo Okamura ${ }^{1}$, Toru Ishigami ${ }^{1}$, Susumu Hasegawa ${ }^{1}$, \\ Noriaki Kato ${ }^{1}$ and Hideto Matsuyama ${ }^{1, *}$ \\ 1 Center for Membrane and Film Technology, Department of Chemical Science and Engineering, \\ Kobe University, 1-1 Rokkodai, Nada-ku, Kobe 657-8501, Japan; sungil.jeon@people.kobe-u.ac.jp (S.J.); \\ rajabzadeh@iust.ac.ir (S.R.); r.okamura@kobe-u.ac.jp (R.O.); t.ishigami@kobe-u.ac.jp (T.I.); \\ s.hasegawa@people.kobe-u.ac.jp (S.H.); noriaki_kato@people.kobe-u.ac.jp (N.K.) \\ 2 Research Centre for Membrnae Separation Processes, Faculty of Chemical Engineering, Iran University of \\ Science and Technology (IUST), Narmak 16846-13114, Tehran, Iran \\ * Correspondence: matuyama@kobe-u.ac.jp; Tel.: +81-78-802-6180
}

Academic Editors: Stephen Gray and Yung-Tse Hung

Received: 24 October 2016; Accepted: 12 December 2016; Published: 20 December 2016

\begin{abstract}
We aimed to investigate the relationship between membrane material and the development of membrane fouling in a membrane bioreactor (MBR) using membranes with different pore sizes and hydrophilicities. Batch filtration tests were performed using submerged single hollow fiber membrane ultrafiltration (UF) modules with different polymeric membrane materials including cellulose acetate (CA), polyethersulfone (PES), and polyvinylidene fluoride (PVDF) with activated sludge taken from a municipal wastewater treatment plant. The three UF hollow fiber membranes were prepared by a non-solvent-induced phase separation method and had similar water permeabilities and pore sizes. The results revealed that transmembrane pressure (TMP) increased more sharply for the hydrophobic PVDF membrane than for the hydrophilic CA membrane in batch filtration tests, even when membranes with similar permeabilities and pore sizes were used. PVDF hollow fiber membranes with smaller pores had greater fouling propensity than those with larger pores. In contrast, CA hollow fiber membranes showed good mitigation of membrane fouling regardless of pore size. The results obtained in this study suggest that the surface hydrophilicity and pore size of UF membranes clearly affect the fouling properties in MBR operation when using activated sludge.
\end{abstract}

Keywords: membrane bioreactor (MBR); membrane fouling; hollow fiber membrane; hydrophilicity; hydrophobicity; wastewater treatment

\section{Introduction}

Membrane bioreactors (MBRs) are a new technology that combines several typical operations (primary sedimentation, activated sludge aeration and sedimentation, and tertiary media filtration) into a single treatment step [1]. MBR has excellent potential for use in a wide range of applications including municipal and industrial wastewater treatment, solid waste digestion, and odor control. Moreover, this technology has many attractive advantages over conventional wastewater treatment processes due to its small footprint, high effluent quality, high volumetric loading, and reduced sludge production [2].

Membranes (flat sheets and hollow fibers) and membrane systems for MBRs are mainly produced by Japanese manufacturers such as Kubota, Tory, Asahi Kasei, and Mitsubishi-Rayon and North American companies such as GE and Koch Membrane Systems. Hollow fibers are mostly used in large plants $\left(>10,000 \mathrm{~m}^{3} /\right.$ day) because of their high surface areas and excellent mass transfer properties, 
while flat sheet membranes are employed for small plants $\left(<5000 \mathrm{~m}^{3} /\right.$ day). Thus, the use of hollow fiber membranes in MBR processes has grown recently [3,4].

For these reasons, the use of MBRs for research, technology, and commercial applications is rapidly advancing across the world. The global MBR market had an estimated value of around US $\$ 425.7$ million in 2014, and the market is rising at a compound annual growth rate (CAGR) of $13.2 \%$ and is expected to reach US $\$ 777.7$ million by 2019 , while the Asia-Pacific market segment reached US $\$ 121.5$ million in 2014 and should reach US $\$ 270.6$ million by 2019 , with a CAGR of $17.4 \%$ between 2014 and 2019 [5]. It can be seen that MBR technology has shown remarkable growth in the Asia-Pacific region, including Japan. However, membrane fouling is a major hindrance to the wider application of MBRs as it results in a sharp decrease in the quantity of produced water, as well as an increase in the energy demand and transmembrane pressure (TMP) [6].

Up to now, many studies on membrane fouling in MBR processes have focused on sludge characteristics, such as mixed liquor suspended solids (MLSS) and extracellular polymeric substances (EPS) [6-9]. Additionally, MBR fouling is affected by operating parameters such as solids retention time (SRT), hydraulic retention time (HRT), dissolved oxygen (DO), food-to-microorganism ratio (F/M), and permeate flux [9-11]. These parameters can indirectly affect membrane fouling by altering the sludge properties [6]. Various methods have been proposed to reduce membrane fouling in MBRs, including chemical and physical cleaning, the use of different membrane geometries (e.g., flat sheet, hollow fiber, and tubular membranes), effective membrane module and reactor design (e.g., membrane packing density and aerator position), membrane surface modification (e.g., hydrophilicity and roughness), and biological antifouling strategies such as quorum quenching and enzymatic disruption [12]. Among these strategies, membrane geometry and surface modification to reduce biofouling have attracted much attention $[13,14]$. In particular, membrane characteristics, such as membrane material, pore size, and hydrophilicity are important factors for membrane fouling because they affect interactions between the membrane surface and the mixed liquor in the bioreactor. It is believed that hydrophilic membranes allow greater membrane fouling mitigation than do hydrophobic membranes $[15,16]$. However, contradictory results have been reported. For example, Matar et al. [17] studied the effect of hydrophobic and hydrophilic membrane surfaces in MBR, and their results showed that fouling behavior in MBR processes are much less dependent on hydrophilicity than previously thought. Choi et al. [18] reported that pore structure had a greater influence on the development of membrane fouling than the hydrophilicity of the membrane surface. As such, it is still debatable whether or not the hydrophilicity of the membrane affects membrane fouling mitigation. In our previous work, we reported the effect of different polymeric membrane materials (polyvinylidene fluoride (PVDF), cellulose acetate butyrate (CAB), and polyvinyl butyral (PVB)) on the relationship between membrane pore size and the development of membrane fouling in a MBR. The membrane fouling of a PVDF hollow fiber membrane decreased as the membrane pore size increased, whereas $C A B$ membranes with smaller pores showed less fouling than those with larger ones [19].

The effects of membrane hydrophilicity on fouling claimed in the reported papers are summarized in Table 1. The objective of this study is to assess the role of membrane surface hydrophilicity and surface pore size in MBR systems. Many research groups have investigated the development of fouling on the surface of microfiltration (MF) membranes, as shown in Table 1. In our study, we fabricated ultrafiltration (UF) hollow fiber membranes with various pore sizes using three different membrane polymeric materials: PVDF, polyether sulfone (PES), and cellulose acetate (CA). The development of membrane fouling on each membrane was investigated by batch filtration testing with activated sludge using a laboratory-scale MBR. 
Table 1. Membrane properties used in previous work and claims regarding the effect of membrane surface hydrophilicity on fouling.

\begin{tabular}{|c|c|c|c|c|c|}
\hline Membrane Material & $\begin{array}{l}\text { Average Pore } \\
\text { Size }(\mu \mathrm{m})\end{array}$ & Hydrophilicity & Configuration & $\begin{array}{c}\text { Affected by } \\
\text { Hydrophilicity }\end{array}$ & References \\
\hline $\begin{array}{c}\text { PVDF } \\
\text { PVDF/PMMA-g-PEG }\end{array}$ & $\begin{array}{c}0.047 \\
0.053-0.089\end{array}$ & $\begin{array}{l}\text { Hydrophobic } \\
\text { Hydrophilic }\end{array}$ & Flat sheet & Yes & [20] \\
\hline $\begin{array}{l}\text { PVDF } \\
\text { PE } \\
\text { PC }\end{array}$ & $\begin{array}{c}0.02-0.3 \\
0.3 \\
0.1-2.5 \\
\end{array}$ & $\begin{array}{l}\text { Hydrophobic } \\
\text { Hydrophilic } \\
\text { Hydrophilic }\end{array}$ & Flat sheet & No & [21] \\
\hline $\begin{array}{l}\text { PETE } \\
\text { PCTE } \\
\text { PTFE }\end{array}$ & $\begin{array}{l}0.1 \\
0.1 \\
0.1\end{array}$ & $\begin{array}{l}\text { Hydrophobic } \\
\text { Hydrophobic } \\
\text { Hydrophobic }\end{array}$ & Flat sheet & No & [18] \\
\hline $\begin{array}{l}\text { PVDF } \\
\text { PTFE } \\
\text { PTFE }\end{array}$ & $\begin{array}{c}0.08 \\
0.3 \\
0.3\end{array}$ & $\begin{array}{l}\text { Hydrophobic } \\
\text { Hydrophobic } \\
\text { Hydrophilic }\end{array}$ & Flat sheet & Yes & [22] \\
\hline $\begin{array}{l}\text { PVDF } \\
\text { PVB } \\
\text { CAB }\end{array}$ & $\begin{array}{c}0.02-0.4 \\
0.02-0.15 \\
0.04-0.2\end{array}$ & $\begin{array}{l}\text { Hydrophobic } \\
\text { Hydrophobic } \\
\text { Hydrophilic }\end{array}$ & Hollow fiber & No & [19] \\
\hline $\begin{array}{l}\text { PVDF } \\
\text { PES } \\
\text { CA }\end{array}$ & $\begin{array}{l}0.02-0.09 \\
0.03-0.14 \\
0.03-0.09\end{array}$ & $\begin{array}{l}\text { Hydrophobic } \\
\text { Hydrophobic } \\
\text { Hydrophilic }\end{array}$ & Hollow fiber & Yes & This work \\
\hline
\end{tabular}

\section{Materials and Methods}

\subsection{Materials}

CA $\left(M w=30,000\right.$, Sigma-Aldrich, St. Louis, MO, USA), PES $\left(M w=65,000\right.$, Ultrason ${ }^{\circledR}$ E6020P, BASF, Tokyo, Japan), and PVDF (Mw = 322,000, SOLEF6020, Solvay, Tokyo, Japan) were used as polymeric membrane materials. Dimethylacetamide (DMAc) and lithium chloride ( $\mathrm{LiCl})$ were purchased from Wako Pure Chemical Industries. Polystyrene latex particles with diameters of 20, 50, 100, and $200 \mathrm{~nm}$ were purchased from Duke Scientific Corporation (Palo Alto, CA, USA). A LIVE/DEAD BacLight Bacterial Viability kit was purchased from Thermo Fisher Scientific (Waltham, MA, USA) and used to stain bacteria. A Pierce BCA Protein Assay kit was purchased from Thermo Scientific. Deionized water $(18.2 \mathrm{M} \Omega \cdot \mathrm{cm}$, Merck Millipore, Billerica, MA, USA) was used to prepare all aqueous solutions and for rinsing. All chemicals were used without further purification.

\subsection{Hollow Fiber Membrane Preparation}

Hollow fiber membranes were prepared using a batch-type wet spinning machine via non-solvent induced phase separation (NIPS) [23]. The preparation conditions are summarized in Table 2. CA and DMAc were mixed for $12 \mathrm{~h}$ at $25^{\circ} \mathrm{C}$, and then left in the solution tank for $2 \mathrm{~h}$ to remove air bubbles. Hollow fibers were extruded from a spinneret with inner and outer tube diameters of 0.8 and $2 \mathrm{~mm}$, respectively. Eventually, they were transferred into a coagulation bath, which induced phase separation and caused membrane formation, and the membrane was wound on a take-up winder. The prepared hollow fiber membranes were kept in pure water until they were characterized. PES and PVDF membranes were prepared in the same way. 
Table 2. Preparation conditions for hollow fiber membranes.

\begin{tabular}{|c|c|c|c|c|c|c|c|c|c|}
\hline \multirow{2}{*}{$\begin{array}{l}\text { Material } \\
\text { Pore size }\end{array}$} & \multicolumn{3}{|c|}{$\mathrm{CA}$} & \multicolumn{3}{|c|}{ PES } & \multicolumn{3}{|c|}{ PVDF } \\
\hline & $<10-30 \mathrm{~nm}$ & $<50 \mathrm{~nm}$ & $<90 \mathrm{~nm}$ & $<10-30 \mathrm{~nm}$ & $<50 \mathrm{~nm}$ & $<140 \mathrm{~nm}$ & $<10-20 \mathrm{~nm}$ & $<40 \mathrm{~nm}$ & $<90 \mathrm{~nm}$ \\
\hline Polymer solution & \multicolumn{3}{|c|}{ CA-DMAc } & \multicolumn{2}{|c|}{ PES-DMAc } & $\begin{array}{l}\text { PES-DMAc } 4 \\
\text { wt } \% \text { water }\end{array}$ & PVDF-DMAc & $\begin{array}{c}\text { PVDF-DMAc } \\
4 \mathrm{wt} \% \mathrm{LiCl}\end{array}$ & $\begin{array}{l}\text { PVDF-DMAc } 4 \text { wt } \% \\
\text { LiCl-2 wt \% water }\end{array}$ \\
\hline $\begin{array}{l}\text { Polymer concentration } \\
\text { (wt \%) }\end{array}$ & 22 & 20 & 16 & 16 & 14 & 14 & 14 & 14 & 14 \\
\hline $\begin{array}{l}\text { Solution temperature } \\
\qquad\left({ }^{\circ} \mathrm{C}\right)\end{array}$ & \multicolumn{3}{|c|}{ Room temperature } & \multicolumn{3}{|c|}{ Room temperature } & \multicolumn{3}{|c|}{ Room temperature } \\
\hline $\begin{array}{l}\text { Polymer solution flow } \\
\text { rate }(\mathrm{g} / \mathrm{min})\end{array}$ & 3.8 & 2.08 & 4.0 & 2.78 & 4.2 & 1.92 & 2.78 & 4.2 & 1.92 \\
\hline $\begin{array}{l}\text { Inner coagulant } \\
\text { (DMAc:Water) }\end{array}$ & $8: 2$ & $6: 4$ & $6: 4$ & $6: 4$ & $6: 4$ & $6: 4$ & $6: 4$ & $6: 4$ & $6: 4$ \\
\hline $\begin{array}{l}\text { Inner coagulant flow } \\
\text { rate }(\mathrm{g} / \mathrm{min})\end{array}$ & 2.96 & 3.5 & 2.96 & 3.49 & 3.42 & 3.05 & 3.49 & 3.42 & 3.05 \\
\hline Air gap (mm) & 60 & 50 & 50 & 25 & 25 & 60 & 25 & 25 & 60 \\
\hline Take-up speed $(\mathrm{m} / \mathrm{s})$ & 0.034 & 0.025 & 0.046 & 0.024 & 0.03 & 0.027 & 0.024 & 0.03 & 0.027 \\
\hline
\end{tabular}




\subsection{Air Bubble Contact Angle Measurement}

The air bubble contact angle of each membrane was measured using a contact angle goniometer (Drop Master 300, Kyowa Interface Science Co., Saitama, Japan). A sample was placed in a glass cell filled with deionized water, an air bubble $(1 \mu \mathrm{L})$ was then released below the sample, and the contact angle between the air bubble, and the surface was measured automatically upon contact [24].

\subsection{Polystyrene Particle Rejection Test}

To estimate the pore sizes of the membranes, a polystyrene particle rejection experiment was performed using the cross-flow method with a single hollow fiber membrane. The polystyrene particles were monodispersed polystyrene latex particles with diameters of 20,50,100, and $200 \mathrm{~nm}$. The feed solution was prepared by adding the latex particles to an aqueous nonionic surfactant $(0.1 \mathrm{wt} \%$, Triton $\mathrm{X}-100$ ), which was forced to permeate through the membrane at a pressure of $0.05 \mathrm{MPa}$. The polystyrene particle concentrations of the feed and the filtrate were measured using a UV-Vis spectrophotometer (U-2000, Hitachi Co., Tokyo, Japan) at a wavelength of $385 \mathrm{~nm}$. Particle rejection was calculated using the following equation: $R(\%)=\left(1-C_{p} / C_{f}\right) \times 100$. Here, $R$ was the rejection, and $C_{p}$ and $C_{f}$ were the polystyrene particle concentrations of the permeate and the feed, respectively. We used the particle diameter when the rejection was $90 \%$ as the pore size of each membrane.

\subsection{Batch Filtration Test Using Single Membrane Module}

Batch filtration tests were conducted to understand the fouling propensity and flux behavior of the membranes in a laboratory-scale MBR. A schematic diagram of the experimental apparatus is shown in Figure 1. Single membrane modules with a membrane fiber length of $7 \mathrm{~cm}$ were prepared using CA, PES, and PVDF hollow fiber membranes. The single membrane modules were installed in a small filtration apparatus with an effective volume of approximately $120 \mathrm{~mL}$. The inside of the filtration apparatus was filled with wastewater supplied by the Shizuoka Prefecture industrial wastewater treatment plant in Japan. The membrane modules were operated under a constant flux of $0.23 \mathrm{~m}^{3} / \mathrm{m}^{2} /$ day. The MLSS, polysaccharide, and protein concentrations were approximately $4000 \mathrm{mg} / \mathrm{L}, 14 \mathrm{mg} / \mathrm{L}$, and $150 \mathrm{mg} / \mathrm{L}$, respectively, while the SRT was set and maintained at 15 days. An aqueous solution of $0.85 \mathrm{wt} \% \mathrm{NaCl}$ was fed into the reactor to prevent concentration of the MLSS. The batch filtration tests were carried out using raw activated sludge without treatment. A detailed procedure has been reported in our previous research [19].

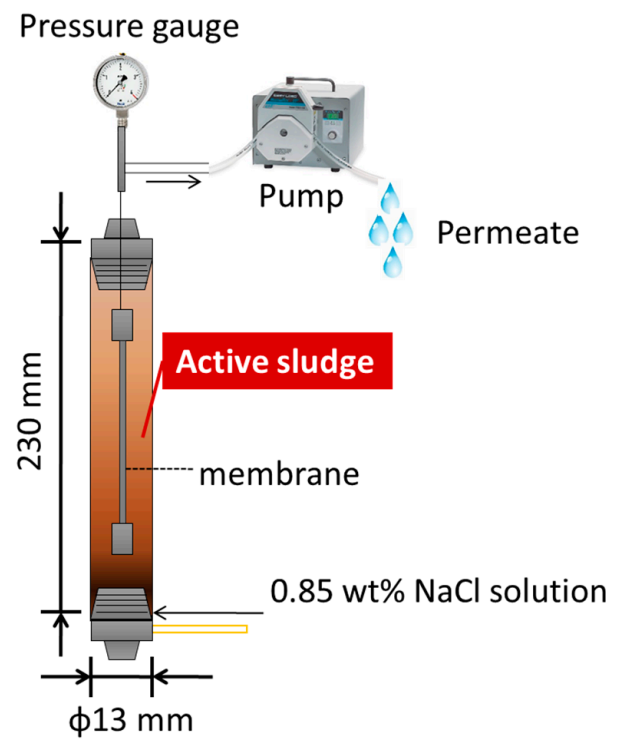

Figure 1. Schematic diagram of the experimental apparatus used in lab-scale batch filtration test. 


\subsection{Membrane Morphology Observations}

A field emission scanning electron microscope (FE-SEM) (JSF-7500F, JEOL Co. Ltd., Akishima, Japan) was used to observe the surface morphology of the membranes. The membranes were fractured into small pieces in liquid nitrogen and then dried overnight in a freeze dryer (FDU-1200 EYELA, Tokyo Rikakikai Co. Ltd., Tokyo, Japan). The dried samples were coated with osmium tetroxide $\left(\mathrm{OsO}_{4}\right)$ prior to SEM analysis in order to minimize sample damage due to the electron beam and to obtain clear images.

\subsection{Microbial Floc Attachment Test}

To evaluate the propensity of microbial flocs to attach to the surface of each membrane, batch attachment tests were carried out. Thin films (thickness: $500 \mu \mathrm{m}$ ) without any pores were prepared by casting films of CA, PES, and PVDF with an applicator and drying them. The films were soaked in $10 \mathrm{~mL}$ of a mixed liquor suspension for $1 \mathrm{~h}$, and then rinsed with a pre-sterilized $0.85 \mathrm{wt} \%$ aqueous solution of $\mathrm{NaCl}$ to remove any suspended solids that had accumulated on the film surface. After that, the bacteria attached to the film surface were stained with a LIVE/DEAD BacLight Bacterial Viability Kit (Life Technologies, Carlsbad, CA, USA). The stained films were then observed using a confocal laser scanning microscope (CLSM, FV1000D, Olympus, Tokyo, Japan) at pH 7.0.

\section{Results and Discussion}

\subsection{Properties of Hollow Fiber Membranes}

Figure 2 shows SEM images of CA, PES, and PVDF hollow fiber membranes prepared using the NIPS process. As shown in Figure 2b, skin layers formed on the outer surfaces of the CA, PES, and PVDF hollow fiber membranes, while the cross-sections shown in Figure 2a indicate that macrovoid structures formed in all the membranes. These macrovoids are typical structures for membranes prepared via NIPS [25]. The three hollow fiber membranes had pores on the inner surfaces, as shown in Figure 2c. Thus, these hollow fiber membranes had asymmetric structures. The pure water permeabilities of the three membranes are shown in Table 3, with CA, PES, and PVDF hollow fiber membranes showing water permeabilities at one bar of 215, 331, and $233 \mathrm{LMH}$, respectively. Thus, the water permeability properties of the three membranes were similar.
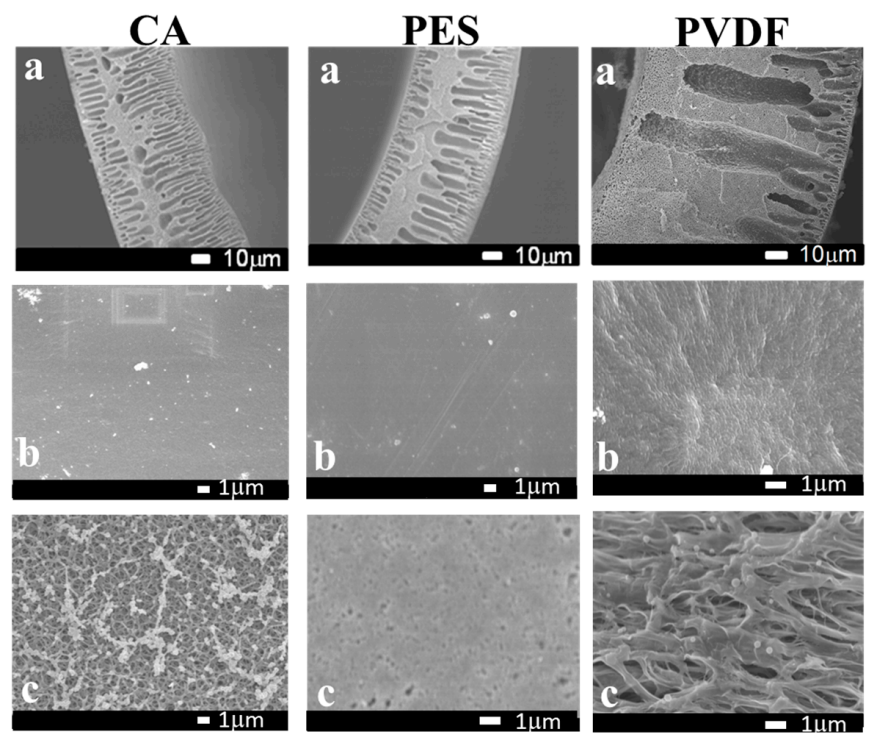

Figure 2. SEM images of cellulose acetate (CA) $(30 \mathrm{~nm})$, polyethersulfone (PES) $(30 \mathrm{~nm})$, and polyvinylidene fluoride (PVDF) $(20 \mathrm{~nm})$ hollow fiber ultrafiltration membranes: (a) cross-sections; (b) outer surfaces; (c) inner surfaces. 
Table 3. Properties of CA, PES, and PVDF hollow fiber membranes.

\begin{tabular}{cccc}
\hline Membrane & CA & PES & PVDF \\
\hline Pure water permeability & $215 \pm 7$ & $331 \pm 22$ & $233 \pm 71$ \\
$\left(\mathrm{~L} / \mathrm{m}^{2} \cdot \mathrm{h} \cdot\right.$ bar $)$ & $<10-30$ & $<10-30$ & $<10-20$ \\
Mean pore size $(\mathrm{nm})$ & 121 & 115 & 94 \\
Air bubble contact angle $\left(^{\circ}\right)$ & & & \\
\hline
\end{tabular}

The rejection properties of the prepared hollow fiber membranes were evaluated using polystyrene latex particles with diameters of 20, 50, 100, and $200 \mathrm{~nm}$. Figure 3 shows the polystyrene particle rejection curves for the hollow fiber membranes. All three membranes showed similar rejection tendencies, and high rejections were obtained even for $30 \mathrm{~nm}$ polystyrene latex particles. Therefore, these membranes were classified as UF membranes. According to the criteria used, the CA, PES, and PVDF hollow fiber membranes showed mean pore sizes of $<30,<30$, and $<20 \mathrm{~nm}$, approximately, respectively. These three membranes with similar water permeabilities and pore sizes were used for the following fouling filtration tests.

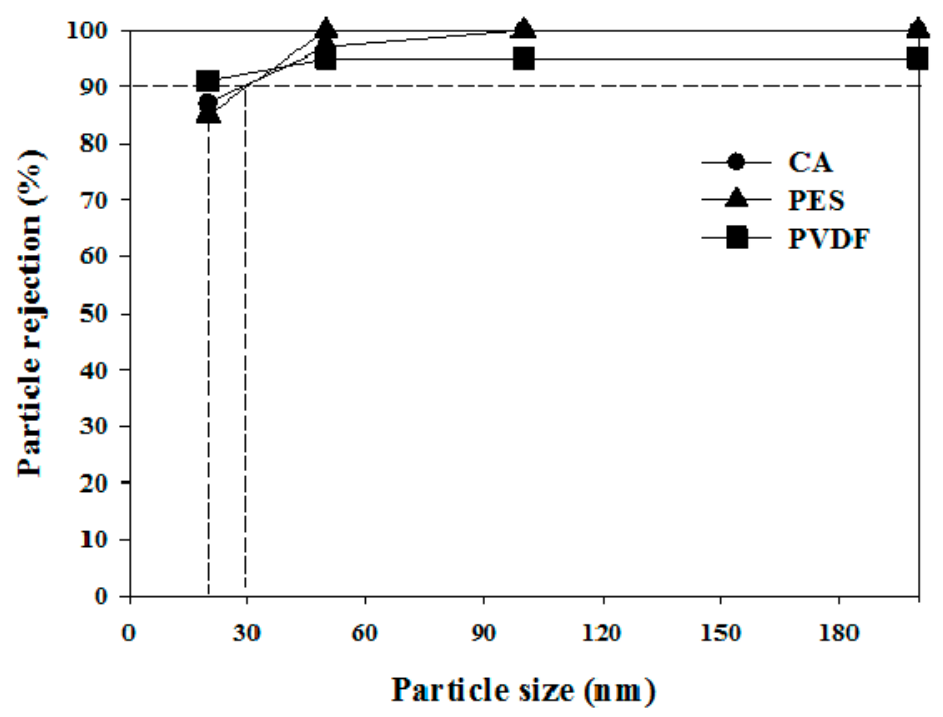

Figure 3. Polystyrene particle rejection results for the prepared membranes.

\subsection{Fouling Behavior in Batch Filtration Tests}

As mentioned in the introduction, whether or not the membrane hydrophilicity affects the mitigation of membrane fouling is still open for debate. In many cases, membranes with different hydrophilicities, water permeabilities, and pore sizes were used for the comparison of fouling properties. Since the water permeability and pore size can also affect the fouling properties, membranes with similar water permeabilities and pore sizes must be used to more accurately examine the effect of membrane hydrophilicity. In this work, three types of hollow fiber membranes (CA, PES, and PVDF) with similar water permeabilities and pore sizes were used to evaluate the effect of material hydrophilicity. The air contact angles of CA, PES, and PVDF were $121^{\circ}, 115^{\circ}$, and $94^{\circ}$, respectively (Table 3). Thus, the hydrophilicities of the materials increase in the order CA $>$ PES $>$ PVDF. Figure 4 shows the membrane fouling results obtained for the three membranes used for MBR water treatment of raw activated sludge. When using the CA membrane, TMP was almost constant and was below $5 \mathrm{kPa}$ throughout the test. On the other hand, the development of membrane fouling with the PES and PVDF membranes increased remarkably. After $60 \mathrm{~min}$, the TMPs decreased in the order of PVDF $>$ PES > CA, which is in agreement with the hydrophobicities of the membranes. Thus, it is clearly shown that hydrophilic membrane materials are preferable for reducing membrane fouling. 
Major membrane foulants are believed to be EPS from bacterial cell lysis, microbial metabolites, and unmetabolized wastewater components [26], including proteins, polysaccharides, nucleic acids, and other polymers [26-28]. Of these major foulants, we believe that hydrophobic fouling materials such as proteins and microorganisms affect the development of fouling on hydrophobic membrane surfaces.

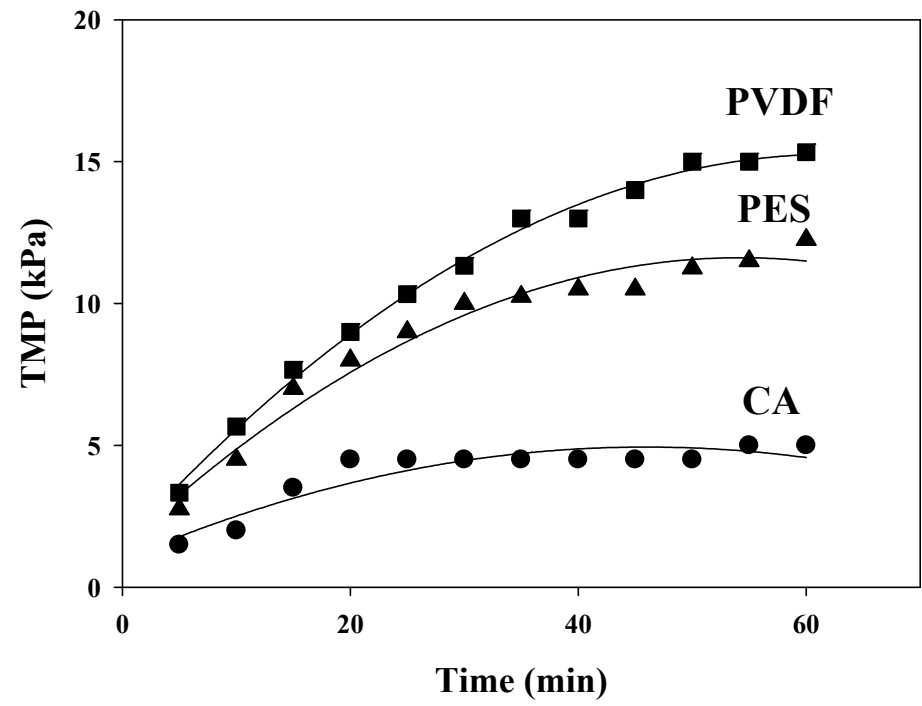

Figure 4. Transmembrane pressure (TMP) changes during batch filtration tests with activated sludge. The pore sizes of CA, PES and PVDF membranes were 30, 30, and $20 \mathrm{~nm}$, respectively.

\subsection{Visualization of the Biofouling on the Film Surfaces}

To understand the attachment properties of the microbial flocs on the prepared films, batch attachment tests with activated sludge were performed. Figure 5 shows the CLSM images of the surface of each polymer film after the attachment test. The amount of fluorescent microbial flocs on the surface of the CA membrane was significantly less than seen for the PES and PVDF membranes. It is hypothesized that the hydrophilicity of the CA membrane play an active role in reducing microbial floc adsorption, which is expected to be beneficial for the antifouling properties of the membrane, as shown in Figure 4.
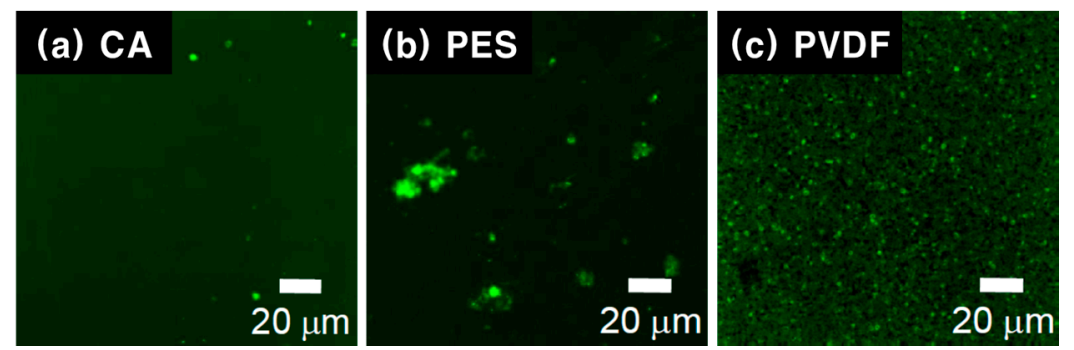

Figure 5. Confocal laser scanning microscope (CLSM) images obtained for the surfaces of thin films of (a) CA; (b) PES; and (c) PVDF after use in batch attachment tests with activated sludge. The surfaces of the films were stained with LIVE/DEAD stain.

\subsection{Effects of Membrane Pore Size on Membrane Fouling}

To investigate the effects of membrane pore size on fouling behavior, MBR experiments were conducted using membranes with different pore sizes. Figure 6 shows the relationship between membrane pore size and fouling rate as determined in the batch filtration tests. In this figure, the fouling rates are denoted by the TMP after $60 \mathrm{~min}$ of filtration. For the CA hollow fiber membrane, 
the effect of pore size was unclear. This is because the fouling of the hydrophilic membrane was reduced, so the effect of the pore size was not significant. However, for PVDF and PES hollow fiber membranes, the fouling propensity decreased sharply with increased pore size. This is in agreement with other research results $[18,21,29,30]$. Marel et al. [31] reported that PVDF with large pores showed greatly reduced membrane fouling in submerged membrane bioreactors. They carried out fouling filtration tests with flat sheet PVDF membranes with different pore sizes $(0.03,0.1$, and $0.3 \mu \mathrm{m})$ to investigate the influence of pore size on fouling behavior. The membrane resistance sharply decreased with increasing pore size. Our previous research on PVDF MF membranes showed a similar trend [19]. The development of membrane fouling on PVDF membranes decreased in the order $0.02>0.25>$ $0.4 \mu \mathrm{m}$. However, the results for the CAB hollow fiber membrane showed the opposite tendency [19]. This indicates that fouling behavior can be affected by complicated factors such as surface chemical properties, surface morphology, pore size, hydrophilic/phobic properties, and solution chemistry. These factors should be considered together for a definite understanding of the fouling behavior in MBR processes.

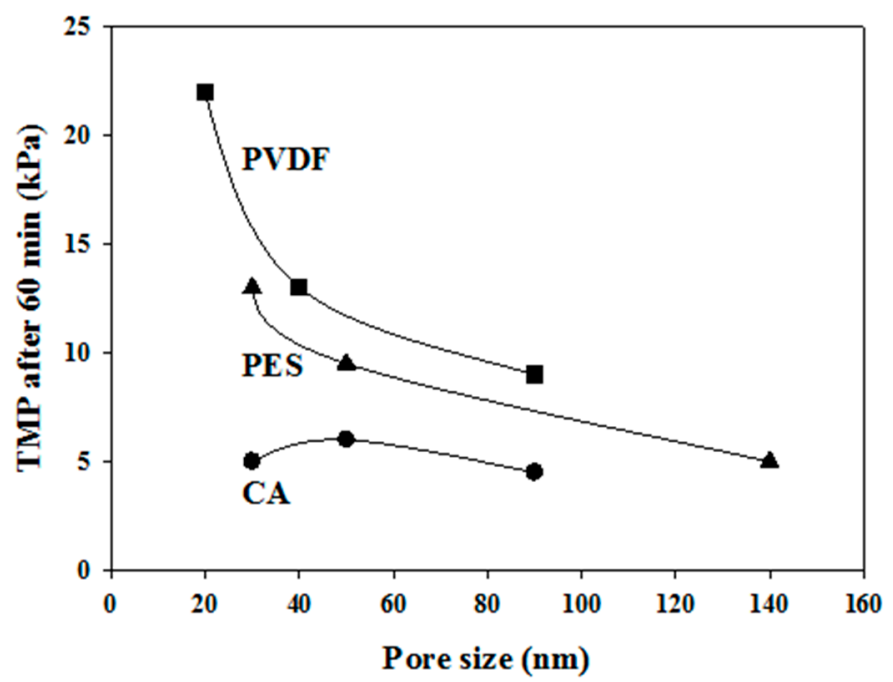

Figure 6. Relationship between membrane pore size and TMP for membranes using different polymer materials.

\section{Conclusions}

In this paper, we investigated the effect of membrane hydrophilicity and pore size on the development of UF membrane fouling in a MBR process. The membrane hydrophilicity was found to affect the membrane fouling. The hydrophilic CA membrane showed good mitigation of membrane fouling, while dramatic biofouling occurred on the PVDF and PES membrane surfaces due to interaction between hydrophobic foulants such as proteins and microorganisms and the hydrophobic membranes. For CA hollow fiber membranes, membrane pore size had no significant effect on fouling mitigation. In contrast, larger pores were found to contribute to the mitigation of membrane fouling for PVDF and PES hollow fiber membranes.

Acknowledgments: This research was partially supported by Grants-In-Aid from the Special Coordination Funds for Prompting Science and Technology, Creating of Innovation Centers for Advanced Interdisciplinary Research Area (Innovative Bioproduction, Kobe) from the Ministry of Education, Culture, Sports, Science, and Technology, Japan.

Author Contributions: Ryo Okamura, Toru Ishigami and Saeid Rajabzadeh conceived and designed the experiments; Ryo Okamura and Toru Ishigami performed the experiments; Sungil Jeon, Saeid Rajabzadeh, Ryo Okamura, Susumu Hasegawa and Noriaki Kato analyzed the data; Sungil Jeon, Saeid Rajabzadeh and Hideto Matsuyama contributed to the writing of the manuscript. 
Conflicts of Interest: The authors declare no conflict of interest.

\section{Abbreviations}

The following abbreviations are used in this manuscript:

$\begin{array}{ll}\text { BSA } & \text { bovine serum albumin } \\ \text { CA } & \text { cellulose acetate } \\ \text { CAGR } & \text { compound annual growth rate } \\ \text { CLSM } & \text { confocal laser scanning microscopy } \\ \text { DMAc } & \text { dimethylacetamide } \\ \text { dissolved oxygen } \\ \text { EPS } & \text { extracellular polymeric substance } \\ \text { FE-SEM } & \text { field emission scanning electron microscope } \\ \text { F/M } & \text { food-to-microorganism ratio } \\ \text { HRT } & \text { hydraulic retention time } \\ \text { LiCl } & \text { lithium chloride } \\ \text { MBR } & \text { membrane bioreactor } \\ \text { MF } & \text { microfiltration } \\ \text { MLSS } & \text { mixed liquor suspended solids } \\ \text { NIPS } & \text { non-solvent induced phase separation } \\ \text { OsO } & \text { osmium tetroxide } \\ \text { PBS } & \text { phosphate buffer solution } \\ \text { PES } & \text { polyether sulfone } \\ \text { PTFE } & \text { polytetrafluoroethylene } \\ \text { PVDF } & \text { polyvinylidene fluoride } \\ \text { SMBR } & \text { submerged membrane bioreactor } \\ \text { SRT } & \text { solids retention time } \\ \text { TIPS } & \text { thermally induced phase separation } \\ \text { TMP } & \text { transmembrane pressure } \\ \text { UF } & \text { ultrafiltration } \\ \text { WWTP } & \text { wastewater treatment plant }\end{array}$

\section{References}

1. Judd, S. The MBR Book; Elsevier: Amsterdam, The Netherlands, 2011.

2. Visvanathan, C.; Aim, R.B.; Parameshwaran, K. Membrane separation bioreactors for wastewater treatment. Crit. Rev. Environ. Sci. Technol. 2000, 30, 1-48. [CrossRef]

3. Cote, P.; Alam, Z.; Penny, J. Hollow fiber membrane life in membrane bioreactors (MBR). Desalination 2012, 288, 145-151. [CrossRef]

4. Katuri, K.P.; Werner, C.M.; Jimenez-Sandoval, R.J.; Chen, W.; Jeon, S.; Logan, B.E.; Lai, Z.; Amy, G.L.; Saikaly, P.E. A novel anaerobic electrochemical membrane bioreactor (AnEMBR) with conductive hollow-fiber membrane for treatment of low-organic strength solutions. Environ. Sci. Technol. 2014, 48, 12833-12841. [CrossRef] [PubMed]

5. Hanft, S. Membrane Bioreactors: Global Markets; BCC Research: Wellesley, MA, USA, 2011.

6. Meng, F.; Chae, S.-R.; Drews, A.; Kraume, M.; Shin, S.-H.; Yang, F. Recent advances in membrane bioreactors (MBRs): Membrane fouling and membrane material. Water Res. 2009, 43, 1489-1512. [CrossRef] [PubMed]

7. Nagaoka, H.; Yamanishi, S.; Miya, A. Modeling of biofouling by extracellular polymers in a membrane separation activated sludge system. Water Sci. Technol. 1998, 38, 497-504. [CrossRef]

8. Ji, J.; Qiu, J.; Wong, F.-S.; Li, Y. Enhancement of filterability in MBR achieved by improvement of supernatant and floc characteristics via filter aids addition. Water Res. 2008, 42, 3611-3622. [CrossRef] [PubMed]

9. Chang, I.S.; Kim, S.N. Wastewater treatment using membrane filtration-effect of biosolids concentration on cake resistance. Process Biochem. 2005, 40, 1307-1314. [CrossRef]

10. Ng, H.Y.; Tan, T.W.; Ong, S.L. Membrane fouling of submerged membrane bioreactors: Impact of mean cell residence time and the contributing factors. Environ. Sci. Technol. 2006, 40, 2706-2713. [CrossRef] [PubMed]

11. Ng, H.Y.; Tan, T.W.; Ong, S.L.; Toh, C.A.; Loo, Z.P. Effects of solid retention time on the performance of submerged anoxic/oxic membrane bioreactor. Water Sci. Technol. 2006, 53, 7-13. [CrossRef] [PubMed]

12. Malaeb, L.; Katuri, K.P.; Logan, B.E.; Maab, H.; Nunes, S.P.; Kaikaly, P.E. A hybrid microbial fuel cell membrane bioreactor with a conductive ultrafiltration membrane biocathode for wastewater treatment. Environ. Sci. Technol. 2013, 47, 11821-11828. [CrossRef] [PubMed] 
13. Yang, H.L.; Chun-Te Lin, J.; Huang, C. Application of nanosilver surface modification to RO membrane and spacer for mitigating biofouling in seawater desalination. Water Res. 2009, 43, 3777-3786. [CrossRef] [PubMed]

14. Nikolaeva, D.; Langner, C.; Ghanem, A.; Rehim, M.A.; Voit, B.; Meier-Haack, J. Hydrogel surface modification of reverse osmosis membranes. J. Membr. Sic. 2015, 476, 264-276. [CrossRef]

15. Santos, A.; Judd, S. The commercial status of membrane bioreactors for municipal wastewater. Sep. Sci. Technol. 2010, 45, 850-857. [CrossRef]

16. Kim, J.O.; Jung, J.T.; Yeom, I.T.; Aoh, G.H. Effect of fouling reduction by ozone backwashing in a microfiltration system with advanced new membrane material. Desalination 2007, 202, 361-368. [CrossRef]

17. Matar, G.; Gonzalez-Gil, G.; Maab, H.; Nunes, S.; Le-Clech, P.; Vrouwenvelder, J.; Saikaly, P.E. Temporal changes in extracellular polymeric substances on hydrophobic and hydrophilic membrane surfaces in a submerged membrane bioreactor. Water Res. 2016, 95, 27-38. [CrossRef] [PubMed]

18. Choi, J.-H.; Park, S.-K.; Ng, H.-Y. Membrane fouling in a submerged membrane bioreactor using track-etched and phase-inversed porous membranes. Sep. Purif. Technol. 2009, 65, 184-192. [CrossRef]

19. Miyoshi, T.; Yuasa, K.; Ishigami, T.; Rajabzadeh, S.; Kamio, E.; Ohmukai, Y.; Saeki, D.; Ni, J.; Matsuyama, H. Effect of membrane polymeric materials on relationship between surface pore size and membrane fouling in membrane bioreactors. Appl. Surf. Sci. 2015, 330, 351-357. [CrossRef]

20. Minehara, H.; Dan, K.; Ito, Y.; Takabatake, H.; Henmi, M. Quantitative evaluation of fouling resistance of PVDF/PMMA-g-PEO polymer blend membranes for membrane bioreactor. J. Membr. Sci. 2014, 466, $211-219$. [CrossRef]

21. Marbelia, L.; Bilad, M.R.; Piassecka, A.; Jishana, P.S.; Naik, P.V.; Vankelecom, I.F.J. Study of PVDF asymmetric membranes in a high-throughput membrane bioreactor (HT-MBR): Influence of phase inversion parameters and filteration performance. Sep. Purif. Technol. 2016, 162, 6-13. [CrossRef]

22. Nittami, T.; Tokunaga, H.; Satoh, A.; Takeda, M.; Matsumoto, K. Influence of surface hydrophilicity on polytetrafluoroethylene flat sheet membrane fouling in a submerged membrane bioreactor using two activated sludges with different characteristics. J. Membr. Sci. 2014, 463, 183-189. [CrossRef]

23. Rajabzadeh, S.; Sano, R.; Ishigami, T.; Kakihana, Y.; Ohmukai, Y.; Matsuyama, H. Preparation of hydrophilic vinyl chloride copolymer hollow fiber membranes with antifouling properties. Appl. Surf. Sci. 2015, 324, 718-724. [CrossRef]

24. Zhou, Z.; Rajabzadeh, S.; Shaikh, A.R.; Kakihana, Y.; Ma, W.; Matsuyama, H. Effect of surface properties on antifouling performance of poly(vinyl chloride-co-poly(ethylene glycol)methyl ether methacrylate)/PVC blend membrane. J. Membr. Sci. 2016, 514, 537-546. [CrossRef]

25. Hashino, M.; Hirami, K.; Ishigami, T.; Ohmukai, Y.; Maruyama, T.; Kubota, N.; Matsuyama, H. Effect of kinds of membrane materials on membrane fouling with BSA. J. Membr. Sci. 2011, 384, 157-165. [CrossRef]

26. Flemming, H.-C.; Wingender, J. Relevance of microbial extracellular polymeric substances (EPSs)-Part II: Technical aspects. Water Sci. Technol. 2001, 43, 9-16. [PubMed]

27. Nagaoka, H.; Nemoto, H. Influence of extracellular polymeric substances on nitrogen removal in an intermittently-aerated membrane bioreactor. Water Sci. Technol. 2005, 51, 151-158. [PubMed]

28. Malamis, S.; Andreadakis, A. Fractionation of proteins and carbohydrates of extracellular polymeric substances in a membrane bioreactor system. Bioresour. Technol. 2009, 100, 3350-3357. [CrossRef] [PubMed]

29. Chen, L.; Tian, Y.; Cao, C.-Q.; Zhang, J.; Li, Z.-N. Interaction energy evaluation of soluble microbial products (SMP) on different membrane surfaces: Role of the reconstructed membrane topology. Water Res. 2012, 46, 2693-2704. [CrossRef] [PubMed]

30. Le-Clech, P.; Chen, V.; Fane, T.A.G. Fouling in membrane bioreactors used in wastewater treatment. J. Membr. Sci. 2006, 284, 17-53. [CrossRef]

31. Marel, P.; Zwijnenburg, A.; Kemperman, A.; Wessling, M.; Temmink, H.; Meer, W.B.D. Influence of membrane properties on fouling in submerged membrane bioreactors. J. Membr. Sci. 2010, 348, 66-74. [CrossRef]

(C) 2016 by the authors; licensee MDPI, Basel, Switzerland. This article is an open access article distributed under the terms and conditions of the Creative Commons Attribution (CC-BY) license (http:/ / creativecommons.org/licenses/by/4.0/). 